\title{
FAKTOR-FAKTOR PEMILIHAN KARIR SEBAGAI AKUNTAN PUBLIK
}

\author{
Viriany \\ Universitas Tarumanagara \\ viriany@fe.untar.ac.id \\ Henny Wirianata \\ Universitas Tarumanagara \\ hennyw@fe.untar.ac.id
}

\begin{abstract}
The purpose of this study is to obtain empirical evidence regarding the effect of financial rewards, professional training, social values, professional recognition, work environment and market considerations on career interest as a public accountant. This study uses primary data with 137 respondents consisting of final year students in the S1 Accounting study program, Faculty of Economics and Business at Tarumanagara University. The results of the study found that in addition to the professional recognition variable, other variables have an influence on career interest as a public accountant.
\end{abstract}

Keywords : career interest as a public accountant.

\begin{abstract}
ABSTRAK
Tujuan dari penelitian ini adalah untuk memperoleh bukti empiris mengenai pengaruh penghargaan finansial, pelatihan profesional, nilai-nilai sosial, pengakuan profesional, lingkungan kerja dan pertimbangan pasar terhadap minat berkarir sebagai akuntan publik. Penelitian ini menggunakan data primer dengan 137 responden yang terdiri dari mahasiswa tingkat akhir di program studi S1 Akuntansi Fakultas Ekonomi dan Bisnis di Universitas Tarumanagara. Hasil penelitian menemukan bahwa selain variabel pengakuan profesional maka variabel lainnya mempunyai pengaruh terhadap minat berkarir sebagai akuntan publik.

Kata kunci: Minat berkarir sebagai akuntan publik.
\end{abstract}

\section{PENDAHULUAN}

Setiap mahasiswa yang sudah berada dalam tingkat akhir pasti menghadapi sebuah pemikiran yaitu kemana mereka akan bekerja, profesi apa yang harus mereka pilih. Mahasiswa lulusan jurusan akuntansi dapat memilih karir sebagai akuntan pendidik, akuntan perusahaan, akuntan pemerintah dan akuntan publik. Akuntan publik adalah suatu profesi yang memberikan jasa sebagai profesional yang telah memiliki izin negara untuk melakukan praktik sebagai akuntan swasta yang bekerja secara independen. Tugas akuntan publik meliputi analisis laporan keuangan, audit laporan keuangan, audit pajak, dan sebagainya. (Harnovinsah, 2017) dalam penelitiannya menemukan pemilihan karir atau profesi sebagai akuntan publik setelah mahasiswa lulus ditentukan oleh ekspektasi atau harapan dan kesempatan yang mereka dapatkan dalam memilih 
karir atau profesi. Pada kelompok responden pertama, penelitian (Harnovinsah, 2017) menemukan bahwa mahasiswa berkeinginan untuk bekerja sebagai akuntan publik karena melihat profesi ini memberikan kesempatan kerja yang lebih baik dan sesuai dengan apa yang selama ini dijalankan dan dipelajari di perkuliahan. Sementara, pada kelompok responden kedua ditemukan bahwa mahasiswa memilih karir sebagai profesi non-akuntan publik karena melihat profesi non-akuntan publik akan memberikan kesempatan kerja yang lebih luas dan memiliki tingkat stres yang lebih rendah. Lulusan akuntansi setiap tahunnya masih sangat banyak di Indonesia, namun tidak banyak yang memutuskan untuk memilih profesi sebagai akuntan publik. Akuntan Publik adalah salah satu dari profesi akuntan yang masih sangat kurang jumlahnya di Indonesia. Institut Akuntan Publik Indonesia (IAPI) mengungkapkan bahwa Indonesia kekurangan jumlah akuntan publik dan masih membutuhkan profesi tersebut dalam jumlah besar, sebagai antisipasi bertumbuhnya sektor bisnis dalam salah satu seminarnya yang diadakan di Jakarta pada bulan Januari 2020. Ketua Umum IAPI menyebutkan jumlah perusahaan Indonesia berdasarkan data wajib pajak badan yang melaporkan Surat Pemberitahuan Tahunan (SPT) tercatat sebanyak 700 ribu perusahaan. Dari jumlah itu, hanya 30 ribu perusahaan yang menggunakan eksternal audit. Angka itu jauh lebih rendah dari kondisi di Thailand yang memiliki 680.000 perusahaan, dengan 62 ribu perusahaan yang menggunakan akuntan publik. IAPI menunjukan bahwa jumlah Akuntan publik yang terdaftar (pemegang izin praktek) sebanyak 1.077 Orang, dan jumlah Akuntan Publik yang masih aktif hanya berjumlah 946 orang, sisanya banyak yang cuti, mengundurkan diri, tidak aktif, meninggal, dan terkena sanksi pembekuan atau tidak berlaku lagi izin akuntan publiknya. Sementara, jumlah KAP yang terdaftar masih aktif menurut Departemen Keuangan sebanyak 387. Mencermati gambaran umum keanggotaan IAPI tersebut, kita patut khawatir akan terjadinya kelangkaan profesi akuntan publik. Sementara itu peluang jasa audit masih sangat luas. Kebutuhan dunia kerja akan akuntan profesional masih sangat tinggi. (Keller, 2010) menyebutkan salah satu hal yang penting dalam meraih sukses adalah pemilihan karir. Selain dipengaruhi oleh ekspektasi dan kesempatan, pemilihan karir oleh mahasiswa juga dipengaruhi oleh informasi dan pengetahuan yang mereka dapatkan selama perkuliahan. Dosen dapat berperan membantu mahasiswa memahami karakteristik dan sifat dari profesi akuntansi (Harnovinsah, 2017). 
Penyusunan dan perancangan material ajar dapat menjadi cara yang efektif dalam memberikan informasi dan pengetahuan yang akan memberikan arah bagi mahasiswa dalam menentukan pilihan karir mereka setelah lulus. Pemilihan karir sebagai akuntan publik dipengaruhi oleh banyak faktor. (Jatmiko, Machmuddah, Suryani, Suhana, \& Laras, 2019) dalam penelitiannya menemukan pertimbangan pasar, pelatihan profesional, lingkungan kerja, nilai-nilai sosial mempengaruhi minat berkarir sebagai akuntan publik, sementara penghargaan finansial dan pengakuan professional tidak memberikan pengaruh terhadap minat mahasiswa dalam memilih karir sebagai akuntan publik. (Asmoro, Wijayanti, \& Suhendro, 2016) sebelumnya melakukan penelitian yang

\section{TELAAH LITERATUR}

\section{Pengertian Akuntan publik}

Profesi akuntan di Indonesia dapat dibedakan menjadi empat, yaitu akuntan perusahaan, akuntan pendidik, akuntan publik, dan akuntan pemerintah (Averus, Nikho, \& Laksito, 2015) dan (Asmoro, Wijayanti, \& Suhendro, 2016). Akuntan perusahaan merupakan akuntan yang bekerja di sebuah perusahaan, akuntan pendidik adalah akuntan yang memiliki tanggung jawab memberikan pendidikan akuntansi, mengembangkan kurikulum, serta melakukan pendidikan di bidang sama dan menemukan hanya pelatihan profesional yang menjadi faktor pemilihan karir sebagai akuntan publik. (Jatmiko, Machmuddah, Suryani, Suhana, \& Laras, 2019) menekankan pentingnya peranan dosen dalam membentuk perspektif positf pada mahasiswa tentang profesi akuntan publik. Melihat pada masih luasnya peluang profesi dan pilihan karir sebagai akuntan publik, maka penelitian ini dilakukan untuk mendapatkan bukti empiris tentang faktor-faktor apakah yang mempengaruhi mahasiswa untuk memilih profesi atau karir sebagai akuntan publik. Faktor-faktor pemilihan karir yang diteliti adalah penghargaan finansial, pelatihan profesional, nilai-nilai sosial, pengakuan profesional, lingkungan kerja, dan pertimbangan pasar.

akuntansi, akuntan publik adalah akuntan yang bekerja di kantor akuntan, serta akuntan pemerintah merupakan akuntan yang bekerja di lembaga pemerintahan (Supriyadi, Jatmika, \& Asnawi, 2020). Menurut Undang-undang Dasar Republik Indonesia No.5 tahun 2011 mengenai Akuntan Publik, Akuntan publik adalah salah satu jenis profesi di bidang akuntansi yang menawarkan jasa profesional terkait bidang akuntansi yang sesuai dengan standar berlaku dan telah mendapatkan izin 
dari negara. Tugas akuntan publik adalah analisis laporan keuangan, audit laporan keuangan, audit pajak dan sebagainya. Bidang jasa akuntan publik meliputi jasa atestasi dan non-atestasi. Jasa atestasi adalah jasa yang mencakup audit umum atas laporan keuangan, pemeriksaan atas laporan keuangan proforma, pemeriksaan atas laporan keuangan prospektif, review atas laporan keuangan dan jasa audit atestasi lainnya. Jasa non-atestasi mencakup jasa yang berhubungan dengan akuntansi, keuangan, manajemen, kompilasi, perpajakan dan konsultasi. (Dalton, Bucheit, \& Mcmillan, 2014) dalam penelitiannya menemukan bahwa terdapat tiga komponen yang mendorong mahasiswa akuntansi memilih karir sebagai akuntan publik yang memberikan jasa audit. Dengan memilih karir sebagai auditor, seorang akuntan publik akan memiliki lebih banyak interaksi dengan klien, memiliki kesempatan kerja di masa depan yang lebih besar, dan memiliki pengetahuan yang lebih luas tentang proses bisnis. Pada umumnya akuntan publik memiliki jenjang karir sebagai berikut: auditor junior, auditor senior, manajer dan yang teratas adalah partner. Auditor junior bertugas melakukan prosedur secara rinci, membuat kertas kerja untuk mendokumentasikan pekerjaan audit yang telah dilaksanakan. Auditor senior bertugas untuk melaksanakan audit, dan bertanggung jawab untuk mengusahakan biaya audit dan waktu audit sesuai rencana, mengarahkan dan meninjau pekerjaan auditor junior. Manajer merupakan pengawas audit yang bertugas membantu auditor senior dalam merencanakan program audit dan waktu audit, meninjau kertas kerja, lapora audit dan management letter. Partner bertanggung jawab atas hubungan dengan klien dan bertanggung jawab secara keseluruhan mengenai audit.

\section{Aspek Penghargaan Finansial}

Penghargaan finansial yang diterima dalam bentuk gaji, bonus, penghasilan dalam bentuk apapun adalah salah satu faktor yang menentukan pemilihan karir. Sesuai dengan realita kenyataan yang ada bahwa semua hal di dunia ini membutuhkan uang, maka tentu saja penghargaan finansial ini merupakan faktor yang sangat penting. Tidak mungkin seseorang akan memilih karir yang tidak memberikan penghargaan finansial yang sepadan dengan pengorbanan yang telah dikeluarkan. Secara khusus penghargaan finansial ini dapat dikatakan sebagai bentuk apresiasi perusahaan kepada karyawannya atas pekerjaan yang dilakukan. Profesi akuntan publik dipercaya merupakan salah satu profesi yang memberikan penghargaan finansial yang besar (Jatmiko, Machmuddah, Suryani, Suhana, \& Laras, 
2019). Dalam melaksanakan pekerjaannya, akuntan publik bekerja melakukan audit tidak hanya di satu perusahaan saja tetapi dapat lebih dari satu perusahaan. Semakin besar kantor akuntan publik dimana seorang akuntan publik bekerja, maka semakin banyak jumlah klien yang akan diaudit sehingga semakin besar pendapatan atau penghargaan finansial yang akan diterima. Selain itu, semakin besar perusahaan klien yang menggunakan jasa akuntan publik, maka semakin besar pula pendapatan yang akan diterima (Hambali, Wuryandini, \& Nahoto, 2018). Oleh karena itu, penghargaan finansial menjadi salah satu faktor penting dalam menentukan pilihan karir sebagai akuntan publik.

\section{Aspek Pelatihan Profesional}

Dalam kerangka standar pendidikan internasional untuk akuntan profesional yang dikembangkan oleh (International Accounting Education Standards Board, 2015) disebutkan bahwa profesi akuntansi yang berkualitas didapatkan dari adanya IPD (Initial Professional Development) dan CPD (Continuing Professional Development). IPD merupakan pengembangan diri tahap awal bagi profesi akuntansi. IPD didapatkan melalui pendidikan, pelatihan yang berkaitan dengan teknis, keahlian profesional, serta hal-hal yang berkaitan dengan etika untuk dapat bekerja secara profesional.
Pengalaman dalam praktek sebagai akuntan publik dan penilaian atas kompetensi yang dimiliki juga menjadi bagian dari IPD seorang akuntan publik. Untuk mempertahankan kompetensinya dan supaya dapat bekerja dengan profesional secara bekelanjutan, profesi akuntansi juga memerlukan CPD yang menjadi tahap pembelajaran dan pengembangan diri (IAESB, 2015). CPD tersebut dalam prakteknya didapatkan dari pelatihan-pelatihan profesional. Pelatihan profesional merupakan berbagai pelatihan yang akan diterima ditempat kerja guna meningkatkan profesionalisme para pekerja. Pelatihan profesional merupakan salah satu faktor yang dipertimbangkan oleh mahasiswa dalam berkarir sebagai akuntan publik karena dengan bertambahnya pengetahuan dan skill maka seseorang dapat meningkatkan nilai dirinya. Selain penghargaan finansial, banyak orang memiliki keinginan untuk mengejar prestasi dan mengembangkan diri.

\section{Aspek Nilai-nilai Sosial}

Nilai - nilai sosial ditunjukkan sebagai faktor yang memperlihatkan kemampuan seseorang pada masyarakatnya atau dengan kata lain nilai sosial adalah nilai seseorang dari sudut pandang orang lain di lingkungannya. Nilai-nilai sosial sering kali dikaitkan dengan salah satu kebutuhan dalam teori hierarki Maslow yaitu 
kebutuhan penghargaan. (Maslow, 1954) mengemukakan teori hierarki kebutuhan yang terdiri dari kebutuhan fisiologis, kebutuhan sosial, kebutuhan rasa aman, kebutuhan penghargaan, dan kebutuhan aktualisasi diri. Terdapat dua jenis kebutuhan penghargaan yaitu harga diri (self respect) dan penghargaan dari orang lain. Kompetensi yang dimiliki seorang akuntan publik dalam bekerja akan membentuk persepsi dan penghargaan dari masyarakat terhadap nilai profesi akuntan publik. Persepsi yang terbentuk dari lingkungan sekitar tentang profesi akuntan publik akan menjadi salah satu motivasi bagi mahasiswa dalam memilih karir sebagai akuntan publik. Nilai sosial menjadi salah satu faktor dalam memilih karir sebagai akuntan publik karena mahasiswa menginginkan kepuasan pribadi, kesempatan berinteraksi, kesempatan menjalankan hobi dan perhatian dari rekan kerjanya. Semakin banyak nilai-nilai sosial yang dipercayai akan mereka peroleh dalam profesi akuntan pulik maka makin tinggi kemungkinan mereka akan memilih karir sebagai akuntan publik.

\section{Aspek Pengakuan profesional}

Pengakuan profesional meliputi hal-hal yang berhubungan dengan pengakuan terhadap prestasi dan merupakan penghargaan yang tidak berwujud finansial. Menurut (Stolle, 1976) pengakuan profesional dipertimbangkan oleh mahasiswa yang memilih profesi akuntan publik, hal ini berarti bahwa dalam memilih profesi tidak hanya mencari penghargaan finansial, tetapi juga ada keinginan untuk mendapatkan pengakuan berprestasi. Pengakuan professional juga berkaitan dengan teori kebutuhan penghargaan dari teori (Maslow, 1954). Semakin tinggi penghargaan dan pengakuan profesional yang diberikan maka semakin besar kemungkinan seseorang untuk memilih karir sebagai akuntan publik.

\section{Aspek Lingkungan kerja}

Lingkungan kerja adalah segala sesuatu yang ada di sekitar para pekerja yang dapat mempengaruhi dirinya dalam menjalankan tugas yang dibebankan. (Stolle, 1976) menyatakan bahwa profesi akuntan perusahaan menurut persepsi mahasiswa akuntansi lebih bersifat rutin dan banyak pekerjaan yang dapat diselesaikan di belakang meja, sedangkan pekerjaan sebagai akuntan publik lebih menarik, lebih membutuhkan banyak waktu, tingkat persaingan dan banyaknya tekanan untuk menghasilkan pekerjaan yang lebih baik. Sifat pekerjaan, tingkat persaingan dan banyaknya tekanan merupakan bagian dari faktor lingkungan pekerjaan. Berkarir sebagai akuntan publik akan memiliki lingkungan kerja dengan tantangan yang berbeda-beda karena adanya tuntutan 
dalam memenuhi apa yang diinginkan klien yang diaudit dan adanya tuntutan tenggat waktu dalam menyelesaikan pekerjaan. Oleh karena itu, lingkungan kerja dimana seorang akuntan publik bekerja akan memberikan pengaruh yang sangat besar untuk mereka bekerja secara produktif (Hambali, Wuryandini, \& Nahoto, 2018). Semakin baik dan kondusif lingkungan perkerjaan yang didapatkan maka semakin tinggi kemungkinan untuk memilih karir sebagai akuntan publik.

\section{Aspek Pertimbangan pasar}

Pertimbangan pasar kerja meliputi keamanan kerja dan tersedianya lapangan kerja atau kemudahan mengakses informasi mengenai lowongan kerja. Keamanan kerja merupakan faktor di mana karir yang dipilih dapat bertahan dalam jangka waktu yang lama, termasuk sebagai akuntan publik. Hal ini sesuai dengan teori kebutuhan fisiologis dan kebutuhan akan rasa aman dari teori (Maslow, 1954), dimana seseorang membutuhkan perlindungan, jaminan keamanan, stabilitas, keteraturan, dan bebas dari rasa takut. Karir sebagai akuntan publik diharapkan bukan menjadi pilihan karir sementara, tetapi dapat terus berlanjut sampai pensiun. Pilihan karir sebagai akuntan publik masih mempunyai pasar yang luas di Indonesia mengingat jumlah akuntan publik yang belum memadai.
Dengan demikian, pertimbangan pasar dapat menjadi faktor yang mempengaruhi pilihan karir sebagai akuntan publik.

\section{Teori Persepsi}

Menurut Gibson (1987), persepsi adalah proses konigtif yang dipergunakan oleh seseorang untuk menafsirkan dan memahami dunia sekitarnya. Setiap orang memberi arti kepada stimulus, maka individu yang berbeda akan melihat hal yang sama dengan cara yang berbeda beda, oleh sebab itu hasil penilaian persepsi antar satu individu dengan individu lain dimungkinkan untuk memiliki nilai yang berbeda. Faktor yang mempengaruhi persepsi menurut Gibson (1987) yaitu : Stereotip, selective perception, characteristic, situational, needs, emotion. Stereotip adalah penyamarataan keyakinan terhadap sekelompok orang tertentu. Istilah stereotip dipakai untuk melukiskan pertimbangan yang dibuat tentang orang-orang atas dasar keanggotaan mereka dalam kelompok etnis. Selective perception atau kepandaian menyaring artinya seseorang akan cenderung memilih informasi yang mendukung pandangan mereka dan cenderung mengabaikan informasi atau petunjuk yang berseberangan dengan dirinya. Characteristic biasanya disebut kepribadian , seseorang akan cenderung memakai dirinya sendiri sebagai ukuran dalam berpersepsi. Situational atau situasi 
yang sering diartikan sebagai kondisi, persepsi seseorang sangat bergantung dari situasi dan kondisi yang sedang dialami oleh orang tersebut. Emotion (emosi), faktor ini akan mempengaruhi persepsi seseorang. Misalnya orang yang sedang senang akan cenderung melihat semuanya baik dan sebaliknya yang sedang kesusahan akan cenderung melihat sesuatunya tidak baik. Berdasarkan beberapa penjelasan persepsi di atas maka persepsi pada hakikatnya adalah proses bagaimana individu melakukan pengamatan melalui penginderaan terhadap obyek tertentu yang kemudian diseleksi, diatur, dan diinterpretasikan untuk menciptakan suatu gambaran yang berarti. Persepsi dalam kehidupan seharihari dideskripsikan sebagai bagaimana cara individu memandang, menilai dan memahami sesuatu atau stimulus yang diterima. Dengan kata lain, persepsi merupakan cara pandang dan gambaran tanggapan individu akan sesuatu hal dengan berbagai pertimbangan dan sumber informasi untuk keputusan akhir sebagai persepsi.

\section{Penghargaan Finansial dan} hubungannya terhadap minat berkarir sebagai akuntan publik

Menurut (Asmoro, Wijayanti, \& Suhendro, 2016) Penghargaan finansial atau gaji dipertimbangkan dalam pemilihan profesi karena tujuan utama seseorang bekerja adalah memperoleh gaji. Kompensasi finansial yang rasional menjadi kebutuhan mendasar bagi kepuasan kerja. Penghargaan finansial diuji dengan tiga butir pernyataan yaitu gaji awal yang tinggi, potensi kenaikan gaji dan tersedianya dana pensiun. (Asmoro, Wijayanti, \& Suhendro, 2016) menemukan bahwa penghargaan finansial berpengaruh signifikan terhadap minat mahasiswa untuk berkarir sebagai akuntansi publik. Hal ini sejalan dengan penelitian (Rindani, 2015) dan (Murdiawati, 2020) yang menyatakan bahwa penghargaan finansial memiliki pengaruh signifikan terhadap minat mahasiswa berkarir sebagai akuntan publik. Sebaliknya, (Jatmiko, Machmuddah, Suryani, Suhana, \& Laras, 2019) menemukan bahwa penghargaan finansial tidak mempengaruhi pilihan karir sebagai akuntan publik. Hal ini karena adanya pandangan bahwa pendapatan sebagai akuntan publik masih minimal namun memiliki tingkat risiko yang lebih besar karena seorang akuntan publik harus bekerja dengan mempertahankan independensi (Jatmiko, Machmuddah, Suryani, Suhana, \& Laras, 2019). Pelatihan profesional dan hubungannya terhadap minat berkarir sebagai akuntan publik

Pelatihan profesional menjadi salah satu pertimbangan mahasiswa dalam memilih 
karir sebagai akuntan publik. Pelatihan profesional yang berkaitan dengan pekerjaan akuntan publik akan menambah pengetahuan dan skill dari akuntan publik. Menurut (Asmoro, Wijayanti, \& Suhendro, 2016) pelatihan profesional berpengaruh signifkan terhadap minat berkarir sebagai akuntan publik. Hal ini sejalan dengan penelitian (Murdiawati, 2020) dan (Jatmiko, Machmuddah, Suryani, Suhana, \& Laras, 2019) yang menyatakan hal yang sama yaitu pelatihan profesional berpengaruh signifkan terhadap minat berkarir sebagai akuntan publik.

\section{Nilai-nilai sosial dan hubungannya terhadap minat berkarir sebagai akuntan publik}

Nilai-nilai sosial adalah nilai yang dipercayai oleh seseorang terhadap sebuah kondisi tertentu. Dalam hal ini nilai-nilai sosial yang dipercayai apabila seseorang memilih menjadi akuntan publik adalah mereka dapat berinteraksi dengan rekan kerja, menjalankan hobi di luar pekerjaan, mendapatkan perhatian dari rekan kerja. Menurut (Murdiawati, 2020) dan (Jatmiko, Machmuddah, Suryani, Suhana, \& Laras, 2019), nilai-nilai sosial berpengaruh signifikan terhadap minat mahasiswa untuk berkarir sebagai akuntan publik. Namun hal ini bertentangan dengan penelitian (Asmoro, Wijayanti, \& Suhendro, 2016) yang menyatakan bahwa nilai-nilai sosial tidak berpengaruh signifikan terhadap minat mahasiswa untuk berkarir sebagai akuntan publik. Pengakuan profesional dan hubungannya terhadap minat berkarir sebagai akuntan publik

Pengakuan profesional seperti pemberian penghargaan terhadap pekerjaan yang dilakukan, promosi jabatan akan menjadi salah satu faktor dalam menentukan karir sebagai akuntan publik. (Febriyanti, 2019) menyimpulkan bahwa pengakuan profesional berpengaruh signifikan terhadap minat berkarir sebagai akuntan publik. Hal sejalan dengan apa yang ditemukan oleh (Asmoro, Wijayanti, \& Suhendro, 2016) dan (Murdiawati, 2020) yang menyatakan bahwa pengakuan profesional berpengaruh signifikan terhadap minat berkarir sebagai akuntan publik. Namun bertentangan dengan penelitian (Rindani, 2015) dan (Jatmiko, Machmuddah, Suryani, Suhana, \& Laras, 2019) yang menyatakan bahwa pengakuan profesional tidak berpengaruh signifikan terhadap minat berkarir sebagai akuntan publik.

\section{Lingkungan kerja dan hubungannya terhadap minat berkarir sebagai akuntan publik}

Lingkungan kerja adalah segala sesuatu yang ada disekitar pekerja dan dapat mempengaruhi dirinya dalam menjalankan tugas-tugas yang dibebankan. Lingkungan 
kerja yang nyaman sebagai akuntan publik akan menjadi salah satu pertimbangan untuk berkarir sebagai akuntan publik. (Febriyanti, 2019) menyimpulkan bahwa lingkungan kerja berpengaruh signifikan terhadap minat berkarir sebagai akuntan publik. (Murdiawati, 2020) dan (Jatmiko, Machmuddah, Suryani, Suhana, \& Laras, 2019) menyimpulkan hal yang sama yaitu lingkungan kerja berpengaruh signifikan terhadap minat berkarir sebagai akuntan publik. Namun hal ini bertentangan dengan penelitian yang dilakukan oleh (Asmoro, Wijayanti, \& Suhendro, 2016)yang menyimpulkan bahwa lingkungan kerja tidak berpengaruh signifikan terhadap minat berkarir sebagai akuntan publik.

Pertimbangan pasar dan hubungannya terhadap minat berkarir sebagai akuntan publik

Pertimbangan pasar meliputi tersedianya lapangan pekerjaan sebagai akuntan publik akan menjadi salah satu faktor untuk memilih berkarir sebagai akuntan pulik. Di Indonesia, pasar karir akuntan publik masih sangat besar mengingat jumlah akuntan publik yang masih minim, (Hapsoro, 2018) menyimpulkan dalam penelitiannya bahwa pertimbangan pasar mempunyai pengaruh signifikan terhadap minat berkarir sebagai akuntan publik. Sejalan dengan (Hapsoro, 2018), (Rindani, 2015) dan (Jatmiko, Machmuddah, Suryani, Suhana, \& Laras, 2019) menyimpulkan hal yang sama yaitu pertimbangan pasar mempunyai pengaruh signifikan terhadap minat berkarir sebagai akuntan publik. Berlawanan dengan hasil penelitian (Asmoro, Wijayanti, \& Suhendro, 2016) yang menyimpulkan bahwa pertimbangan pasar tidak mempunyai pengaruh signifikan terhadap minat berkarir sebagai akuntan publik.

\section{Kerangka Pemikiran dan Hipotesis}

Hipotesis yang dikembangkan adalah berikut ini:

Ha1 = Penghargaan Finansial berpengaruh signifikan terhadap minat berkarir sebagai akuntan publik

$\mathrm{Ha} 2=$ Pelatihan profesional berpengaruh signifikan terhadap minat berkarir sebagai akuntan publik

Ha3 = Nilai-nilai sosial berpengaruh signifikan terhadap minat berkarir sebagai akuntan publik

Ha4 = Pengakuan profesional berpengaruh signifikan terhadap minat berkarir sebagai akuntan publik

Ha5 = Lingkungan kerja berpengaruh signifikan terhadap minat berkarir sebagai akuntan publik

Ha6 = Pertimbangan pasar berpengaruh signifikan terhadap minat berkarir sebagai akuntan publik

Kerangka pemikiran hubungan antara variabel penghargaan finansial, pelatihan profesional, nilai-nilai sosial, pengakuan profesional, lingkungan kerja dan 
pertimbangan pasar terhadap minat ditunjukkan pada gambar berikut: berkarir sebagai akuntan publik

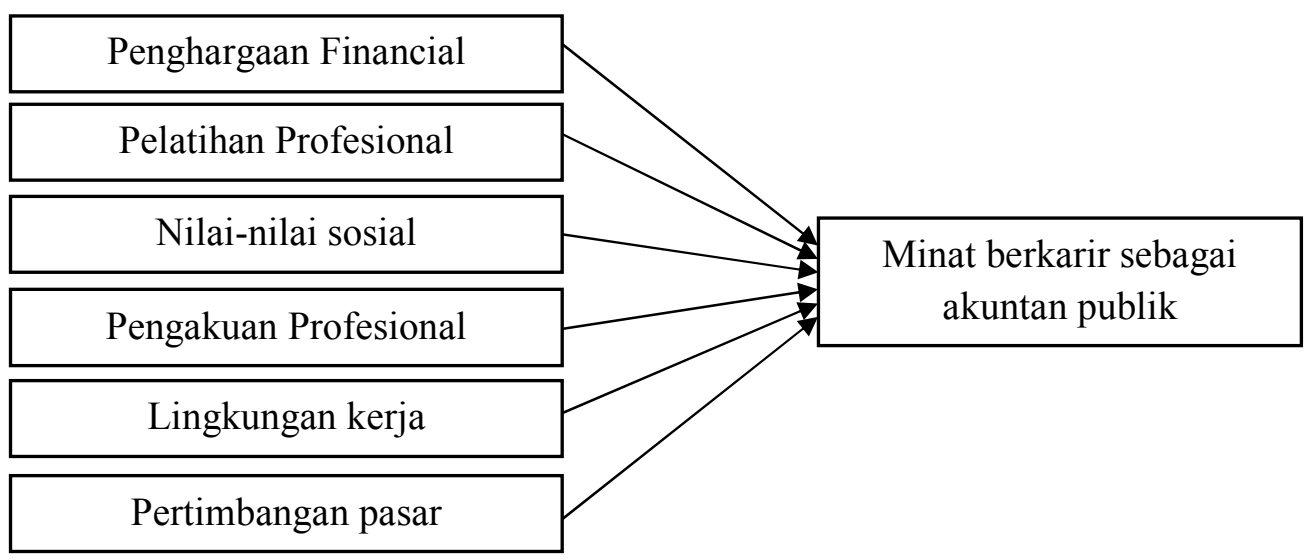

Gambar 1. Model Penelitian

\section{METODELOGI PENELITIAN}

\section{Pengertian Populasi dan Sampel}

Populasi dalam penelitian ini adalah mahasiswa Fakultas Ekonomi dan Bisnis Universitas Tarumanagara Program Studi S1 Akuntansi. Teknik pengambilan sampel dalam penelitian ini adalah purposive sampling yaitu teknik pengambilan sampel secara sengaja dengan persyaratan sampel yang diperlukan. Kriteria sampel adalah mahasiswa Program Studi S1 Akuntansi Fakultas Ekonomi dan Bisnis Universitas Tarumangara yang masih aktif pada semester akhir dan telah menempuh mata kuliah Pemeriksaan Akuntan.

\section{Operasionalisasi Variabel Penelitian}

Variabel dependen adalah variabel minat berkarir sebagai akuntan publik (Y) terdiri dari satu instrumen pertanyaan untuk mengukur ya atau tidaknya minat responden dalam berkarir sebagai akuntan publik. Variabel independen terdiri dari 6 variabel yaitu penghargaan finansial, pelatihan profesional, nilai-nilai sosial, pengakuan profesional, lingkungan kerja, dan pertimbangan pasar. Variabel penghargaan finansial terdiri dari tiga indikator penelitian yaitu :penghargaan finansial atau gaji awal yang tinggi, manfaat pensiun yang lebih baik, dan potensi kenaikan penghargaan finansial atau gaji. Variabel pelatihan profesional terdiri dari empat indikator penelitian yaitu variasi pelatihan kerja, pelatihan dari profesional, pelatihan formal dan pengalaman kerja. Variabel nilai-nilai sosial terdiri dari empat indikator penelitian yaitu pemberian jasa kepada masyarakat, interaksi dengan orang lain, personal job satisfication dan gengsi pekerjaan (prestige). Variabel pengakuan profesional terdiri dari empat indikator 
penelitian yaitu kesempatan untuk berkembang, pengakuan prestasi, keahlian politik dalam pekerjaan dan memerlukan berbagai keahlian untuk mencapai sukses. Variabel lingkungan kerja terdiri dari enam indikator penelitian yaitu lingkungan yang menyenangkan, kantor yang menarik, jam kerja yang fleksibel, suasana kompetisi, toleransi dalam penampilan dan target kerja yang jelas. Variabel pertimbangan pasar terdiri dari tiga indikator penelitian yaitu mengenai jaminan kerja, pekerjaan

\section{HASIL DAN PEMBAHASAN}

\section{Uji Validitas dan Reliabilitas}

Uji validitas dilakukan untuk melihat apakah suatu instrumen mampu mengukur apa yang diinginkan dan mengungkapkan data dari variabel yang diteliti secara tepat. Valid jika nilai corrected item total correlation $>$ nilai $\mathrm{r}$ tabel dengan $\mathrm{df}(\mathrm{n}-2)=$ 0,1678. Karena semua nilai corrected item $>0,1678$ berarti semua butir pertanyaan pada X1, X2, X3, X4, X5, X6 sudah valid. Hasil dari pengujian validitas atas variabelvariabel yang digunakan dalam penelitian yang banyak dibutuhkan dan kemudahan informasi lapangan pekerjaan.

\section{Teknik Pengumpulan Data}

Penelitian ini menggunakan data primer yaitu kuesioner yang menggunakan aplikasi google form. Kuesioner dibagikan ke mahasiswa yang memenuhi kriteria pemilihan sampel. Pengukuran variabel menggunakan skala likert 1-5 point mulai dari STS (sangat tidak setuju) skala 1, TS (tidak setuju) skala 2, N (netral) skala $3, \mathrm{~S}$ (Setuju) skala 4, sampai dengan SS (sangat setuju) skala 5 .

ini dinyatakan valid. Uji Reliabilitas adalah pengujian yang menunjukkan apakah suatu instrumen yang digunakan untuk memperoleh informasi dapat dipercaya untuk mengungkap informasi di lapangan sebagai alat pengumpulan data. Alpha Conbrach merupakan koefisien reliabilitas yang paling umum yang dapat digunakan. Suatu variabel dikatakan reliable jika memberikan nilai Alpha Conbrach >0,6. Hasil dari uji reliabilitas dapat dilihat pada tabel di bawah ini: 
Tabel 1. Hasil Uji Reliabilitas

\begin{tabular}{|l|c|c|c|}
\hline \multicolumn{1}{|c|}{ Variabel } & Cronbach Alpha & Nilai Kritis & Kesimpulan \\
\hline Penghargaan finansial & 0.646 & 0,6 & Reliabel \\
\hline Pelatihan profesional & 0.619 & 0,6 & Reliabel \\
\hline Nilai-nilai sosial & 0.602 & 0,6 & Reliabel \\
\hline Pengakuan profesional & 0.617 & 0,6 & Reliabel \\
\hline Lingkungan kerja & 0.713 & 0,6 & Reliabel \\
\hline Pertimbangan pasar & 0.610 & 0,6 & Reliabel \\
\hline
\end{tabular}

Sumber: Data diolah (2020)

\section{Uji -2Log Likelihood}

Uji ini dilakukan dengan tujuan untuk melihat perubahan yang terjadi pada model regresi setelah variabel independen dimasukkan ke dalam model. Tabel iteration history pada block 0 menunjukkan nilai -2Loglikelihood saat variabel independen (cash holding, firm size, profitability, dan financial leverage) tidak dimasukkan ke dalam model dan sedangkan tabel iteration history pada block 1 menunjukkan nilai -1Loglikelihood saat variabel independen telah dimasukkan ke dalam model. Berikut ini dapat dilihat tabel hasil pengujian $-2 \log$ likelihood saat sebelum dan sesudah dimasukkannya variabel independen ke dalam model. Adapun hasil dari uji 2Log Likelihood dapat dilihat pada tabel di bawah ini:

Tabel 2. Hasil Uji -2Likelihood

\begin{tabular}{|c|c|}
\hline Step & -2Loglikelihood \\
\hline Block Number $=0$ & 178.665 \\
\hline Block Number $=1$ & 134.676 \\
\hline
\end{tabular}

Sumber: Data diolah (2020)

Tabel 2 menjelaskan mengenai hasil nilai 2Log likelihood setelah uji dilaksanakan. Untuk melihat baik atau tidaknya suatu model regresi yang digunakan dapat diketahui dengan melihat perbandingan dari nilai -2Log likelihood. Penurunan nilai dari -2Log likelihood awal pada step block number $=0$ ke -2Loglikelihood akhir pada step block number $=1$ menunjukkan bahwa model regresi penelitian dapat dikatakan baik. Tabel diatas menunjukkan bahwa step block number $=0$ atau beginning block memiliki nilai $-2 \log$ likelihood sebesar 178.665 sedangkan pada step block number $=1$ atau method enter memiliki nilai -2Log likelihood sebesar 134,676. Berdasarkan hasil tersebut di atas dapat diambil kesimpulan bahwa konstanta sendiri tanpa ditambahkan dengan variabel bebas memiliki nilai sebesar 178.665 dan 
setelah ditambahkan variabel bebas maka nilai konstanta turun menjadi sebesar 134,676. Penurunan nilai ini menunjukkan bahwa model regresi ini dapat dikatakain baik untuk melakukan prediksi pengaruh

\section{Uji Nagelkerke's R Suare.}

Uji ini dilakukan dengan tujuan untuk melihat seberapa besar pengaruh variabel independen terhadap variabel dependen penghargaan finansial, pelatihan profesional, nilai-nilai sosial, pengakuan profesional, lingkungan kerja dan pertimbangan pasar minat berkarir sebagai akuntan publik.

Hasil dari uji Nagelkerke's $R$ Square dapat dilihat pada tabel 3 berikut ini:

Tabel 3. Hasil Uji Nagelkerke's R Square

\begin{tabular}{|c|c|}
\hline Step & Nagelkerke's $R$ Square \\
\hline 1 & 0,377 \\
\hline \multicolumn{2}{|c|}{ Sumber: Data diolah (2020) }
\end{tabular}

Nilai Nagelkerke's $R$ Square pada tabel 3 menunjukkan hasil sebesar 0,377 atau sebesar 37,7\%. Hal ini berarti bahwa $37,7 \%$ variasi dari variabel minat berkarir sebagai akuntan publik dapat dijelaskan oleh variabel independennya yaitu penghargaan finansial, pelatihan profesional, nilai-nilai sosial, pengakuan profesional, lingkungan kerja dan pertimbangan pasar.. Sedangkan sisanya yaitu sebesar $62,3 \%$ dijelaskan oleh variabel-variabel lain yang tidak terdapat pada penelitian ini. Nilai Nagelkerke's $R$ Square yang sebesar $37,7 \%$ menunjukkan bahwa sebenarnya model regresi pada penelitian ini masih banyak memiiki kekurangan. Namun model regresi pada penelitian ini masih dapat digunakan karena model masih cukup untuk dapat menjelaskan mengenai variabel dependen pada penelitian ini.

\section{Uji Hosmer dan Lemeshow's Goodness of} Fit Test

Uji ini dilakukan dengan tujuan untuk melihat kecocokan antara data empiris dengan model. Pada uji Hosmer dan Lemeshow's Goodness of Fit Test apabila hasil nilai signifikan $(p$-value $)>0,05$ maka dapat dikatakan bahwa model regresi yang digunakan dapat dikatakan fit atau cocok sehingga model regresi tersebut dapat digunakan untuk melakukan analisa lebih lanjut. Fit atau cocok disini berarti antara model regresi dan data aslinya terdapat kecocokan. Hasil dari uji Hosmer dan Lemeshow's Goodness of Fit Test dapat dilihat pada tabel 4 berikut. 
Tabel 4. Hasil Hosmer dan Lemeshow's Goodness of Fit Test

\begin{tabular}{|c|c|}
\hline Step & Sig. \\
\hline 1 & 0,451 \\
\hline
\end{tabular}

Sumber: Data diolah (2020)

Tabel 4 menunjukkan hasil uji Hosmer dan Lemeshow's Goodness of Fit Test. Pada tabel dapat dilihat bahwa hasil nilai signifikan (p-value) adalah sebesar 0,451 atau dapat dikatakan bahwa nilai signifikan $(p$-value $)>0.05$. Hal ini berarti bahwa model regresi dan data aslinya memiliki kecocokan dan dengan kata lain model regresi pada penelitian ini cocok untuk dilakukan analisa lebih lanjut. Hal ini juga menjelaskan bahwa model regresi yang digunakan dapat menjelaskan hubungan antara variabel independen dan variabel dependen.

\section{Uji Omnibus Test}

Uji Omnibus Test ini dilakukan dengan tujuan untuk melihat gambaran atas seberapa besar pengaruh dari variabel independen mempengaruhi variabel dependen secara simultan. Hasil uji Omnibus Test yang memiliki nilai signifikan $<0,05$ menunjukkan bahwa variabel independen pada penelitian yang ditambahkan terhadap model dapat mempengaruhi variabel dependen secara simultan. Hasil dari uji Omnibus Test dapat dilihat pada tabel 5 berikut ini:

Tabel 5. Hasil Uji Omnibus

\begin{tabular}{|c|c|c|}
\hline & df & Sig. \\
\hline Step & 6 & 0,000 \\
\hline Block & 6 & 0,000 \\
\hline Model & 6 & 0,000 \\
\hline
\end{tabular}

Sumber: Data diolah (2020)

Hipotesis:

$\mathrm{H}_{0}$ : Tidak ada pengaruh seluruh variabel bebas terhadap variabel dependen

Ha: Terdapat pengaruh seluruh variabel bebas terhadap variabel dependen

Tabel 5 menunjukkan nilai signifikansi $=$ $0,000<0,05$ sehingga $\mathrm{H}_{0}$ ditolak, berarti terdapat pengaruh seluruh variabel bebas terhadap variabel dependen (fit). Dengan kata lain bahwa variabel independen pada penelitian ini yang terdiri dari penghargaan finansial, pelatihan profesional, nilai-nilai sosial, pengakuan profesional, lingkungan kerja dan pertimbangan pasar yang ditambahkan pada model dapat mempengaruhi variabel dependen dalam penelitian ini yaitu minat berkarir sebagai akuntan publik. 
Uji Tingkat Ketepatan Prediksi Model

Regresi Logistik
Hasil uji tingkat ketepatan prediksi model regresi logistik dapat dilihat pada tabel berikut

ini:

Tabel 6. Hasil Uji Tingkat Ketepatan Prediksi

\begin{tabular}{|c|c|c|c|c|c|}
\hline & & \multirow{3}{*}{ Observed } & \multicolumn{3}{|c|}{ Predicted } \\
\hline & & & \multicolumn{2}{|c|}{$\mathrm{Y}$} & \multirow{2}{*}{ Percentage Correct } \\
\hline & & & tidak & $\mathrm{Ya}$ & \\
\hline \multirow[t]{3}{*}{ Step 1} & $\mathrm{Y}$ & Tidak & 30 & 19 & 61.2 \\
\hline & & $\mathrm{Ya}$ & 14 & 74 & 84.1 \\
\hline & & all Percentage & & & 75.9 \\
\hline
\end{tabular}

Sumber: Data diolah (2020)

Uji tingkat ketepatan prediksi ini dilakukan dengan tujuan untuk menilai perkiraan antara hasil perhitungan yang benar dan hasil perhitungan yang salah dari uji yang telah dilaksanakan atau untuk menguji tingkat ketepatan pengelompokan variabel dependen (terikat). Pengelompokan variabel dependen pada penelitian ini terbagi menjadi 2 (dua) yaitu mahasiswa yang mempunyai minat berkarir sebagai akuntan publik dan mahasiswa yang tidak mempunyai minta berkarir sebagai akuntan publik. Persentase ketepatan prediksi dari model adalah 75,9\%, berarti dari 137 sampel terdapat 104 sampel yang diprediksi dengan tepat.

\section{Uji Hipotesis}

Uji hipotesis menggunakan Uji Wald yang juga merupakan uji multivariative secara serentak. Pengujian multivariative yang secara serentak ini dilakukan dengan tujuan untuk memperoleh hasil mengenai pengaruh masing-masing variabel independen secara individual terhadap variabel dependen dengan menggunakan teknik analisis regresi binary logictic. Metode yang digunakan pada pengujian multivariative secara serentak adalah metode enter dengan tinggi tingkat signifikansi sebesar 5\%. Hasil atas pengujian multivariative secara serentak pada penelitian ini ditunjukan oleh tabel 7 berikut ini:

Tabel 7. Hasil Uii Wald

\begin{tabular}{|l|l|r|r|r|r|r|r|}
\hline & \multicolumn{1}{|c|}{ B } & \multicolumn{1}{c|}{ S.E. } & \multicolumn{1}{c|}{ Wald } & \multicolumn{1}{l|}{ df } & \multicolumn{1}{c|}{ Sig. } & \multicolumn{1}{|c|}{ Exp(B) } \\
\hline Step 13 & Penghargaan Finansial & -.426 & .147 & 8.370 & 1 & .004 & .653 \\
\cline { 2 - 8 } & Pelatihan Profesional & .281 & .124 & 5.175 & 1 & .023 & 1.325 \\
\cline { 2 - 8 } & Nilai Sosial & .238 & .103 & 5.370 & 1 & .020 & 1.269 \\
\cline { 2 - 8 } & Pengakuan Profesional & -.125 & .129 & .932 & 1 & .334 & .883 \\
\cline { 2 - 8 } & Lingkungan Kerja & .173 & .078 & 4.870 & 1 & .027 & 1.189 \\
\cline { 2 - 8 } & Pertimbangan Pasar & .412 & .145 & 8.119 & 1 & .004 & 1.510 \\
\cline { 2 - 8 } & Constant & -8.985 & 2.520 & 12.708 & 1 & .000 & .000 \\
\hline
\end{tabular}

Sumber: Data diolah (2020) 
Berdasarkan hasil uji Wald, terdapat 6 variabel $\mathrm{X}$ yang mempengaruhi $\mathrm{Y}(\mathrm{X} 1, \mathrm{X} 2$,
X3, X4, X5 dan X6) dan persamaan yang terbentuk adalah:

$$
\ln \frac{p}{1-p}=-8,985-0,426 X_{1}+0,281 X_{2}+0,238 X_{3}-0,125 X_{4}+0,173 X_{5}+0,412 X_{6}
$$

\section{Interpretasi Persamaan Menggunakan}

\section{Nilai odds Ratio (Exp B):}

Arti $\mathrm{B}_{1}=$ semakin tinggi penghargaan finansial $\left(\mathrm{X}_{1}\right)$ maka kemungkinan seseorang berminat menjadi akuntan publik sebesar 0,653 kali lipat dibandingkan dengan yang penghargaan finansialnya lebih rendah. Arti $\mathrm{B}_{2}=$ semakin tinggi pelatihan profesional $\left(\mathrm{X}_{2}\right)$ maka kemungkinan seseorang berminat menjadi akuntan publik sebesar 1,325 kali lipat lebih tinggi dibandingkan dengan yang pelatihan profesionalnya lebih rendah. Arti $\mathrm{B}_{3}=$ semakin tinggi nilai sosial $\left(\mathrm{X}_{3}\right)$ maka kemungkinan seseorang berminat menjadi akuntan publik sebesar 1,269 kali lipat lebih tinggi dibandingkan dengan yang nilai sosialnya lebih rendah. Arti $\mathrm{B}_{4}=$ semakin tinggi pengakuan profesional $\left(\mathrm{X}_{4}\right)$ maka kemungkinan seseorang berminat menjadi akuntan publik sebesar 0,883 kali lipat dibandingkan dengan yang pengakuan profesionalnya lebih rendah.
Arti $\mathrm{B}_{5}=$ semakin baik lingkungan kerja $\left(\mathrm{X}_{5}\right)$ maka kemungkinan seseorang berminat menjadi akuntan publik sebesar 1,189 kali lipat lebih tinggi dibandingkan dengan yang lingkungan kerjanya buruk. Arti $\mathrm{B}_{6}=$ semakin tinggi pertimbangan pasar $\left(\mathrm{X}_{6}\right)$ maka kemungkinan seseorang berminat menjadi akuntan publik sebesar 1,510 kali lipat lebih tinggi dibandingkan dengan yang pertimbangan pasarnya lebih rendah.Hasil tabel 7 di atas dapat disimpulkan juga bahwa variabel penghargaan finansial, pelatihan professional ,nilai sosial, lingkungan kerja, dan pertimbangan pasar berpengaruh signifikan terhadap minat berkarir sebagai akuntan publik. Sedangkan variabel lainnya yaitu pengakuan profesional tidak berpengaruh secara signifikan terhadap minat berkarir sebagai akuntan publik.

Adapun pembahasan lebih lanjut dapat dilihat di tabel di bawah ini: 
Tabel 8. Kesimpulan atas Hasil Penelitian

\begin{tabular}{|l|l|c|c|l|}
\hline Hipotesis & Variabel Independen & $\begin{array}{c}\text { Signifikansi } \\
\text { yang } \\
\text { ditetapkan }\end{array}$ & Signifikansi & Hasil Hipotesis \\
\hline $\mathrm{Ha}_{1}$ & Penghargaan Finansial & 0,05 & 0,004 & Berpengaruh \\
\hline $\mathrm{Ha}_{2}$ & Pelatihan Profesional & 0,05 & 0,023 & Berpengaruh \\
\hline $\mathrm{Ha}_{3}$ & Nilai-nilai sosial & 0,05 & 0,020 & Berpengaruh \\
\hline $\mathrm{Ha} 4$ & Pengakuan profesional & 0,05 & 0,334 & Tidak berpengaruh \\
\hline $\mathrm{Ha} 5$ & Lingkungan kerja & 0,05 & 0,27 & Berpengaruh \\
\hline $\mathrm{Ha}$ & Pertimbangan pasar & 0,05 & 0,004 & Berpengaruh \\
\hline $\mathrm{Uji}$ Omnibus (Simultan) & 0,05 & 0,000 & $\begin{array}{l}\text { Berpengaruh secara } \\
\text { Simultan }\end{array}$ \\
\hline
\end{tabular}

Sumber: Data diolah (2020)

Ha 1 diterima yang artinya penghargaan finansial berpengaruh signifikan terhadap minat berkarir sebagai akuntan publik. Hanya saja penghargaan finansial secara rutin tidak berpengaruh besar terhadap minat berkarir sebagai akuntan publik, responden lebih memilih penghargaan finansial seperti uang pensiun yang menjadi pertimbangan mereka berkarir sebagai akuntan publik. Hal ini sejalan dengan penelitian dari (Rindani, 2015), (Asmoro, Wijayanti, \& Suhendro, 2016) dan (Murdiawati, 2020) yang menyatakan bahwa penghargaan finansial berpengaruh secara signifikan terhadap minat berkarir sebagai akuntan publik. Hipotesis yang kedua yaitu $\mathrm{Ha} 2$ diterima yang artinya bahwa pelatihan profesional berpengaruh secara signifikan terhadap minat berkarir sebagai akuntan publik. Artinya pelatihan profesional yang baik akan menjadi pertimbangan dalam berkarir sebagai akuntan publik. Hal ini sejalan dengan penelitian dari (Asmoro, Wijayanti, \&
Suhendro, 2016), Murdiawati (2020), dan (Jatmiko, Machmuddah, Suryani, Suhana, \& Laras, 2019). Hipotesis ketiga (Ha3) menyatakan bahwa nilai sosial berpengaruh signifikan terhadap minat berkarir mahasiswa sebagai akuntan publik. Ha3 diterima artinya nilai sosial berpengaruh terhadap minat berkarir mahasiswa sebagai akuntan publik. Hal ini sejalan dengan penelitian dari (Murdiawati, 2020) dan (Jatmiko, Machmuddah, Suryani, Suhana, \& Laras, 2019), tetapi tidak sejalan dengan hasil penelitian (Asmoro, Wijayanti, \& Suhendro, 2016) yang menemukan nilai sosial tidak berpengaruh terhadap pilihan karir sebagai akuntan publik. Hipotesis keempat yaitu Ha4 yang menyatakan bahwa pengakuan profesional berpengaruh signifikan terhadap minat berkarir sebagai akuntan publik ditolak yang aritnya pengakuan profesional tidak menjadi pertimbangan dari responden untuk berkarir sebagai akuntan publik. Hal ini 
sejalan dengan penelitian dari (Rindani, 2015) dan (Jatmiko, Machmuddah, Suryani, Suhana, \& Laras, 2019) yang menyatakan bahwa pengakuan profesional tidak berpengaruh signifikan terhadap minat berkarir sebagai akuntan publik. Hipotesis selanjutnya yaitu hipotesis kelima (Ha5) yang berbunyi lingkungan kerja berpengaruh secara signifikan terhadap minat berkarir sebagai akuntan publik diterima yang artinya lingkungan kerja yang baik akan menjadi pertimbangan responden untuk berkarir sebagai akuntan publik. Hal ini sejalan dengan penelitian (Febriyanti, 2019), (Murdiawati, 2020), dan (Jatmiko,

\section{SIMPULAN}

Hasil penelitian menunjukkan bahwa penghargaan finansial dan pengakuan professional bukan merupakan faktor yang mempengaruhi pemilihan karir sebagai akuntan publik karena tidak memberikan pengaruh signifikan. Pelatihan profesional, nilai sosial, lingkungan kerja, dan pertimbangan pasar memiliki pengaruh signifikan, yang artinya merupakan faktor yang mempengaruhi pilihan karir sebagai akuntan publik. Penelitian ini mempunyai keterbatasan waktu pelaksanaan sehingga responden hanya terbatas pada mahasiswa tingkat akhir pada Program Studi S1
Machmuddah, Suryani, Suhana, \& Laras, 2019), yang menyatakan bahwa lingkungan kerja berpengaruh signifikan terhadap minat berkarir sebagai akuntan publik. Hipotesis terakhir yaitu $\mathrm{Ha} 6$ berbunyi pertimbangan pasar berpengaruh signifikan terhadap minat berkarir sebagai akuntan publik diterima dengan arti pertimbangan pasar masih menjadi salah satu variabel yang mempengaruhi minat berkarir sebagai akuntan publik. Hal ini sejalan dengan hasil penelitian dari Yusmarini (2019), (Jatmiko, Machmuddah, Suryani, Suhana, \& Laras, 2019), dan (Rindani, 2015).

Akuntansi Fakultas Ekonomi dan Bisnis
Universitas Tarumanagara. Penelitian
selanjutnya dapat menambah responden
yang diperluas menjadi mahasiswa
Program Studi S1 Akuntansi di luar
lingkungan Universitas Tarumanagara.
Faktor lain yang dapat dimasukkan untuk
penelitian selanjutnya diantaranya adalah
peran dari tenaga pendidik/dosen dalam
membentuk persepsi mahasiswa
menentukan pilihan karir sebagai akuntan
publik serta cakupan kurikulum dan proses
pembelajaran pada Program Studi S1
Akuntansi.




\section{DAFTAR PUSTAKA}

Asmoro, T. K., Wijayanti, A., \& Suhendro. (2016). Factors Affecting Accounting Students in Selecting Career as Public Accountant. Journal of Management and Business, Vol.15, No.1, Maret $2016,75-84$.

Averus, Nikho, \& Laksito, H. (2015). Analisis Persepsi Mahasiswa Akuntansi Dalam Memilih Karir (Studi Empiris Mahasiswa Akuntansi S1 Di Perguruan Tinggi Di Semarang). Diponegoro Journal of Accounting, Volume 4, Nomor 2, 114.

Dalton, D. W., Bucheit, S., \& Mcmillan, J. J. (2014). "Audit And Tax Career Paths In Public Accounting: An Analysis Of Student And Professional Perceptions". Accounting Horizons, Vol. 28, No.2 , 213-231.

Febriyanti, F. (2019). Faktor-faktor yang mempengaruhi minat mahasiswa akuntansi dalam pemilihan karir sebagai akuntan publik. Jurnal Akuntansi Vol.6, No.1 Universitas Serang Raya .

Ghazali, I. (2011). Aplikasi Analisis Multivariate Dengan Program SPSS: Semarang: Badan Penerbit: UNDIP.

Hambali, I. R., Wuryandini, A. R., \& Nahoto, S. (2018). Pengaruh Penghargaan Financial, Lingkungan
Kerja, Dan Pertimbangan Pasar Kerja Terhadap Pemilihan Karir Sebagai Akuntan Publik Pada Mahasiswa Akuntansi (Studi Pada Perguruan Tinggi Negeri Dan Swasta Di Provinsi Gorontalo). Journal Of International Conference Proceedings (JICP), Vol. 1, No. 2, 1-13.

Hapsoro. (2018). Analisis Faktor-Faktor yang mempengaruhi minat mahasiswa akuntansi berkarir sebagai akuntan publik (studi kasus terhadap mahasiswa STIE YKPN Yogyakarta). Yogyakarta: STIE YKPN.

Harnovinsah. (2017). Career Decision of Accounting Students and Its Influencing Factors: A Study of University Accounting Students in DKI Jakarta, Indonesia. International Journal of Finance and Accounting, Vol. 6, No. 2 , 59-65.

International Accounting Education Standards Board. (2015). Framework for International Education Standards for Professional Accountans and Aspiring Professional Accountants. New York: International Federation of Accountants.

Jatmiko, B., Machmuddah, Z., Suryani, A., Suhana, \& Laras, T. (2019). Career Choice as a Public Accountant in Accounting Students in the City of 
Semarang Indonesia: Aspects that are Considered. International Journal of Accounting and Taxation, Vol. 7., No. $2,20-26$.

Keller, P. L. (2010). A Theory of Reasoned Action Model of Accounting Students' Career Choice in Public Accounting Practices in The Post-Enron. J. Applied Accounting Res, Vol.11, No.1 , 58-73.

Maslow, A. (1954). Motivation and Personality. New York: Harper and Bros.

Murdiawati, D. (2020). Faktor-faktor yang mempengaruhi minat mahasiswa Akuntansi di Surabaya untuk memilih karir menjadi akuntan publik. Surabaya: STIE Perbanas.

Rindani, A. (2015). Faktor-faktor yang mempengaruhi minat mahasiswa Akuntansi untuk berkarir sebagai akuntan publik (Studi Kasus pada Perguruan Tinggi dengan Program Studi Akuntansi yang terakreditasi B yang terdapat di Pakan Baru. Pekan Baru: Universitas Riau.
Sarli, S. H. (2017). Pengaruh penghargaan Finansial, pertimbangan pasar kerja dan lingkungan keluarga terhadap minat menjadi akuntan public (Studi Empiris mahasiswa S1 Akuntansi Universitas Negeri dan Swasta Kota Padang). Padang: Universitas Padang.

Stolle, C. D. (1976). Student's views of the public and industrial accountant. . Journal of accounting .

Supriyadi, S. G., Jatmika, D., \& Asnawi. (2020). Factors Affecting Career Selection Of Accounting Students To Become Public Accountants. International Journal of Economics, Business and Accounting Research (IJEBAR) Vol. 4, , 305-309.

Yurmaini. (2019). Faktor-faktor yang mempengaruhi pemilihan karir mahasiswa jurusan akuntansi sebagai akuntan public (Studi kasus pada mahasiswa jurusan akuntansi Fakultas Ekonomi Universitas Al Washliyah Medan). Medan: Universitas Al-Washiyah. 